\title{
Cyprus Court Interpreters During the Ottoman Period
}

\author{
Osmanlı Dönemi Kıbrıs Mahkeme Tercümanlı̆̆ı
}

\section{Güven DİNÇ* Cemil ÇELIK ${ }^{* *}$}

\begin{abstract}
The Ottoman Government continuously employed dragoman and court interpreters in order to provide communication between the people and the administration where the people did not speak Turkish, as well as sometimes using interpreters in certain levels of the administration. The court interpreters facilitated relations between the people and the justice system, while the dragoman facilitated communications between those people who did not speak Turkish and the provincial administration. In Cyprus where there was a particular rayah population, the use of court interpreters dates from the Ottoman conquest of the island. In this study, based upon the Cyprus Shari'a Registers (Sijils), it was established that all Cyprus court interpreters were selected from among the Cypriot Greeks, with the exception of one Turkish interpreter who was appointed after the events of 1821. The Cypriot Greek interpreters were expected to be reliable and fair. They were not subject to dismissal as long as they fulfilled their duties responsibly. Court interpreters provided communications between the Cypriot Greek community and the justice system, acting for them in cases, as well as interpreting and translating petitions and papers. Cyprus court interpreters, together with other representatives of the Cypriot Greek community, had a very great power, an indicator of decentralization visible across the country in the $18^{\text {th }}$ century. Some of the court interpreters were found to have been promoted to the rank of Cyprus dragoman. The economic wealth of the Cyprus court interpreters is an indication of their power.
\end{abstract}

Keywords: Cyprus, court, court interpreter, shari'a register, Cypriot Greek, Armenian

Özet: Osmanlı Devleti, yönetimin belirli kademelerinde zaman zaman tercüman kullandığı gibi halkın Türkçe bilmediği yerlerde halkın yönetimle olan iletişimlerini sağlamak üzere devamlı surette saray tercümanları ve mahkeme tercümanları kullanmıştır. Bunlardan saray tercümanları Türkçe bilmeyen halkın vilayet yönetimiyle olan iletişimlerini sağlarken mahkeme tercümanları ise adalet mekanizmasıyla bağlantılarını yerine getirmekteydi. Türkçe bilmeyen belirli bir reâyânın yaşadığı Kıbrıs'ta mahkeme tercümanlığı kullanılması adanın fethine kadar uzanmaktadır. Kıbrıs Şer'iyye Sicilleri temelinde yapılan bu araştırmada Kıbrıs mahkeme tercümanlarının 1821 olayları akabinde atanan bir Türk tercüman haricinde Rumlardan seçildiği tespit edilmiştir. Seçilen bu tercümanların güvenilir ve adil olmaları beklenirdi. Görevlerini hakkıyla yerine getirdikleri sürece azil edilmezlerdi. Mahkeme tercümanları, mütercimlik, hüccetlerin ve dilekçelerin tercümesi yanında davalarda vekillik de yaparak Rum toplumun adalet mekanizmasıyla iletişimlerini sağlamışlardır. Kıbrıs mahkeme tercümanları XVIII. yüzyılda ülke genelinde görülen desantralizasyonun bir göstergesi olarak diğer Rum toplumu temsilcileri ile birlikte oldukça büyük güç ve kudrete sahip olmuşlardır. Bazı mahkeme tercümanlarının Kıbrıs saray tercümanlığına yükseldiğine de şahit olunmaktadır. Kıbrıs mahkeme tercümanlarının ekonomik durumları da bunların ne kadar büyük güce sahip olduklarını kanıtlar niteliktedir.

Anahtar Sözcükler: Kıbrıs, mahkeme, mahkeme tercümanı, şer'iye sicili, Rum, Ermeni

\footnotetext{
*Yrd. Doç. Dr., Akdeniz Üniversitesi, Edebiyat Fakültesi, Tarih Bölümü, Antalya, gdinc@akdeniz.edu.tr

** Dr., cemilcelik736@yahoo.com.tr
} 
Different aspects of the Ottoman judicial organization have been investigated (Inalc1k, 1957, 149-151; Jennings, 1978a, 133-172; Gerber, 1994; Ortayl1, 1994; Peirce, 2003; Ekinci, 2004). The topic of interpreters, whose duties were to eliminate the differences in the languages employed between people who came to the qadi (judge) court and its staff, has not to date been sufficiently investigated. Employing local monographs the attempt is made here to portray the role of the Nicosia court interpreter-ship under the Ottoman administration.

Various studies are available concerning the court interpreter-ship during the course of the Ottoman state. The most well-known of these are K. Çiçek's studies (1996, 47-52; 2002, 2-15). Although Çiçek's works addressed this topic within the Ottoman judicial organization within a general framework, in terms of the resources and the examples which are mainly on Cyprus, this research has a different importance for this analysis.

Çiçek stated that his first article $(1996,47-52)$ should be regarded as a "introduction" to the study of court interpreters, due to the absence of this particular area of study in the past. Although that precious study was described by Çicek in a modest manner as an "introduction" to the topic, he tried to assess court interpreter-ship as far as the documentation he found would permit. Çiçek's second article (2002, 2-15) analysing the years between 1698 and 1726 is similar to the first one in terms of its contents and resources. Çiçek's articles which can be regarded as the first articles in this area, contributed to our study and from which we have gained much.

In this study, in the particular case of Cyprus, the attempt is made to describe the Cyprus court interpreter-ship during the Ottoman period. In this period, the questions as to the influence of interpreters upon Cyprus society, the reflection of state level reforms on this institution, the general course of both the state and Cyprus society upon this institution were investigated using documentary sources.

\section{Court Interpreters in the Ottoman Judiciary}

The Ottoman State contained a wide variety of peoples, religions and languages within extensive land boundaries. The Ottoman tradition of government recognized this diversity as a wealth and did not initiate a policy of oppression aiming for the assimilation of this diversity. A consequence of this was that when the Ottoman State ended, many nation states arose from its dismemberment. As a result of this policy of cultural association rather than assimilation, the office of court interpreter-ship, inherited from Islamic traditional judicial practice, was retained as a functioning useful institution (The earliest court interpreters at Shari'a courts were employed in the $8^{\text {th }} \mathrm{c}$., if not earlier, see Hallaq, 2009, 52).

According to Islamic law, zimmis (non-Muslim) were free to bring legal cases between themselves to the Shari'a court. However, all cases between a Muslim and a zimmi had to be heard in the qadi's court. On the other hand, qadis who were appointed in each region would not be expected to know the local language; interpreters had to be employed in order to ensure communication between the qadis and the people in those cities where different languages were spoken. For this reason, interpreters were appointed to courts from the early days of Islam (Atar, 1979, 146; Jennings, 1978b, 250).

The "Dragoman", (in western sources) the Palace Interpreter or the Diwan Interpreter (the Diwan of the province), was the name of the official who was employed to facilitate the relations of people with the state where most of the people were not Turkish or could not speak Turkish (Hill, 1972, 104-116; Veinstein, 2000, 610-611). Likewise, court interpreters were used to provide communications between people who did not speak Turkish and the system of justice. These interpreters were chosen from Arabs in regions densely populated with Arabs, and Greeks, in those regions densely populated with Greeks (Çiçek, 1996, 47-52). For example, 
Arab interpreters were employed in places such as: Aleppo, Jerusalem, Baghdad, Selahiye and Bankusa, Likewise Greek interpreters were employed in the Peloponnese, Crete etc. (Orhonlu, 1975, 20; Orhonlu, 1979, 179).

Cyprus was one of the places where large numbers of court interpreters were employed due to the fact that the Cypriot Greek (Rum) and the Turkish-Muslim populations were the majority populations on the island. This, of course, raised the problem of language employed in the courts. Considering the numbers of visits of non-Muslims to the Qadi courts in Cyprus from the very start of Ottoman rule, the need for Cypriot Greek interpreters revealed itself (Jennings, 1993, 69; Erdoğru, 2001, 12).

The use of interpreters at the Nicosia court began with the conquest of the island and the establishment of the Ottoman judicial system. However, the first documented interpreter was Toma, found in this position in 1610 (KȘS., 3, 72/9). The interpreter Toma was recorded among witnesses in court. The other interpreters who worked in the first period after Toma were Zaya (1633, KŞS., 4, 1/1), Lazetin (1676, KŞS., 5, 3/1), Yani (1677, KŞS., 5, 89/1), Lorenzo (1677, KŞS., 5, 89/1) and Lazanya (1698, KŞS.,6, 43/2).

\section{The Selection and Appointment of Court Interpreters}

There were predefined criteria in determining those people who would work in the Shari'a courts (Atar, 1979). There were particular criteria employed in the selection of judges, clerks and bailiffs; likewise there were clearly established criteria employed in the selection of court interpreters. In selecting court interpreters, the applicant had to know the local language well, be fair, righteous and reliable (Çiçek, 1996, 49).

Court interpreters had a special importance in articulating the rayahs' problems in the courts and thus in ensuring justice (Atar, 1979, 149). Therefore, court interpreters had a very important role between the local subjects and judges and they would have been well accepted amongst the rayah population and had their trust (KŞS., 5, 89/1; Çiçek, 1996, 49).

The selection and the appointment of court interpreters lay within the jurisdiction of the judges (or regends) according to the specified criteria. The Qadis selected the interpreters and forwarded their names to the centre for appointment. The appointment as interpreter was realized through the issuance of a berat (royal diploma). For example, with the death of Yani, another man called Lorenza was notified as being worthy of this task and a berat was issued; and in consequence of this berat, Lorenza was appointed to the Nicosia court interpreter-ship. In the berat, it was stated that the new interpreter should do his task duly and any attempt to manipulate him was forbidden (KŞS., 5, 89/1).

“Akzâ kuzâti'l-müslimîn, Lefkoşa Kâdîsı olan Mevlânâ Süleyman zîde fizâ'ilüh û südde-i sa âdetime mektûb gönderüb medîne-i Lefkoşa mahkemesinde tercümân olan Yani nâm zimmî mürd olub yeri hâlî ve hidmet-i lâzimesi mu'attal kalmağın râfi'-i tevkî̀'-i refì' $i$ 'ş-şân-ı hâkânî Lorenzo nâm zimmî içün muhill ü müstehıkkdır deyü tevcîh olunub berât-l şerîfim verilmek bâbinda inâyet recâsı arz etmeğin tevcîh idüb işbu berât-l sa'âdet-âyât ve behcet-gâyâtı verdim ve buyurdum ki ba'de'l-yevm mezkûr Lorenzo varub mahkeme-i mezbûrede mürd olan Yani yerine tercümân olub hidmeti- lâzimesin bî-kusûr mer 'î ve mü'eddâ klldıdan sonra ol bâbda efrâd-l âferîde milh ü mâni" ve dâfi "olmayub dahl ve ta 'arruz kllmaya şöyle bileler alâmet-i şerîfe i'timâd kulalar fî-evâhir-i şehr-i Şevvâli'l-mükerrem li-sene semâne ve semânîn ve elf".

From the documents, it is evident that pishkash (Lambton, 1994, 145-158) was given to the 
treasury as another condition for appointment to the post of court interpreter-ship. For example, an appointment berat was issued to Corci v. Mihail in exchange for 1.600 akches in February 1703 (Shawwal 1114) (BOA., AE.SMST.II.-37/3634). In another example, Yerolimo v. Yani was appointed to the Nicosia court interpreter-ship in October 1703 (Jumada Al-Thani 1115), in exchange for 3.000 akches paid by him to the treasury. (BOA., AE.SMST.II. -37/3634).

On the other hand, it is not possible to state that all of the court interpreter-ships were appointed in this way. For instance, in a document dated March 1709 it is recorded that Yerelimo v. Yani, who was working as a court interpreter with a "berât-l şerif-i âlîşân", thought he was not good enough to carry out this job and he passed this office to Yerelimo v. Madiyo in exchange for a hundred and eighty piasters (KŞS., 7, 19/1). K. Çiçek $(1996,50)$, concluded that the court interpreter-ship was being conducted dependent upon the "gedik" system (kind of a leasehold).

As can be seen from the documents, as long as they did their work responsibly and complaints were not received concerning them, they would not be fired. The interpreter Yerolimo for example also provides information about the end of their tasks. Interpreter Yerelimo v. Yani transferred his right of interpreter-ship, saying he would not be able to carry out this task properly anymore and left this work in exchange for some fee. Leaving the job would be through resignation because of some insufficiency, but also through the transference of this task to another in exchange for a sum of money.

Court interpreters working in Cyprus were selected continuously from the Cypriot Greek community until 1821. Due to the consequences of the Greek revolt on the island in 1821 (Dinç, 2010, 82-107), a Turk was employed after this date for a period in the Nicosia court interpretership. The reason for this was that the Cypriot Greek selected court interpreters were involved in the events of 1821 (BOA., MAD. d., 9764, 89/5; BOA., MAD. d., 9764, 378/1). As a result, after the events of 1821, a Turk called Süleyman Nuri was appointed to the court interpreter-ship (KŞS., 30, 3/3, H. 5 Dhu Al-Qi'dah 1236/A.D. 4 August 1821). In addition, it should also be noted that immediately after the 1821 events, there was a significant decrease in referrals of Cypriot Greeks to the Shari'a court.

Though Cyprus court interpreters were selected continuously from the Cypriot Greek community, it is not known if court interpreters were appointed from only among certain families or whether a certain family was able to monopolise the profession.

\section{The Duties of Court Interpreters}

Since the court interpreters' role was to communicate between rayahs who did not speak Turkish and judge and defendants, they had a special value in enunciating the problems of the rayahs in the court and thus enabling the administering of justice (KŞS., 29, 36, hük.3; KŞS., 38,180 , hük.1).

Interpreters are known to have undertaken the task of translating petitions in Greek (KŞS., 28, 250, hük.3), of documents issued by the courts (KŞS., 29, 36, hük. 3; KŞS., 38, 180, hük.1) as well as intervening between the judge and defendants.

Since court interpreters provided a kind of liaison between the judges and those Cypriot Greeks who did not speak Turkish, they sometimes worked as the proxy (wakil, vekil) of the Cypriot Greeks. For example, when the Archbishop Baisios v. Yerolomi died, the new Archbishop who inherited, appointed the court interpreter Haci Yani v. Hristofi as a representative for himself in the lawsuit which was opened against him by other inheritors (KŞS., 19, 44/2).

In another example Dimitri v. Yorgi from the Aya Andoni quarter appointed the court 
interpreter Hristofaci v. Gavrili as a proxy for inheritance from his wife (KMA., Zabit Defteri, $10,10 / 1)$.

In another case, Şerife Hatun and Yorgaki v. Hristoğlu from the Debbağhane quarter appointed Hac1 Mustafa and the court interpreter Yorgaki respectively as their proxies in a real estate sale between Şerife bint-i Mustafa and Yorgaki v. Hristoğlu. (KŞS., 24, 2/2, "tarafindan takrîr-i işritâ-i âtiyü'l-beyâna vekîl olan mahkeme tercümânı Haci Yorgaki’').

Court interpreters, although not directly a part of their duties, could also be responsible for the repair and maintenance of the court building. For example Haci Yorgaki v. Hristoğlu spent 455 piasters 7 paras, a sum which was to be paid back to him, for the repair and maintenance of roof, fixtures, glass and so forth, in the years 1805 and 1806 (1220) (KŞS., 25, 25/2).

There were people in the service of the court interpreters to help them. For example, while interpreter Nicola was making translations between court officials and defendants, there was someone next to him who helped him. In the documents, a person called Yorgi is recorded as assisting Nicola (tâbi 'i tercümân-ı mersûm) and he assisted Nicola at intensive court trials (KŞS., 24, 2/2; KŞS., 24, 5/1). In the same way, Solomon was an amanuensis who helped the court interpreter Simion (KŞS., 26, 146/1), Yani (KŞS., 28, 123/1) and Yani Kafali worked as a servant under the interpreter Hristoğlu (KŞS., 28, 250/3).

The main task of the court interpreters in the Shari'a courts was to enable communication between those people who did not speak Turkish and qadi and other parties, and so if the participants knew how to speak Turkish, they were not needed. In these cases where all parties spoke Turkish, court interpreters are not found amongst the witnesses. The documents recording cases where interpreters served or where they are recorded amongst the witnesses are certainly from those cases concerning the rayah. In such documents one of the participants was definitely from the rayahs. In other words, if the participants consisted of only Turkish people, the interpreters did not serve in that case.

Since court interpreters were available during trials, they were natural witnesses of current trials. For this reason, they are recorded amongst the witnesses in many documents. The point that should be noted is that most of the documents where the interpreters were recorded as witnesses were court cases between non-Muslims. However, in cases between a Muslim and a non-Muslim, the court interpreter is rarely recorded as a witness (KŞS., 18, 43/1; KŞS., 28, $250 / 3$ ). In some cases, the presence of an interpreter in the court was also mentioned, this is a clear indication that the trial was executed through an interpreter (KŞS., 28, 211/1, "mahkeme-i mezbûre tercümânı Hristoğlu hâzır olduğu hâlde"; KȘS., 28, 253/1, "mahkeme-i mezbûre Rûm Tercümanı Hristoğlu hâzır olduğu hâlde").

Another point about the tasks of the Cyprus court interpreters is whether the Cypriot Greeks appointed to this task made interpreter-ship only for the Cypriot Greeks or did they also serve other ethnic groups such as the Armenians and the Jews etc.? There was no person permanently employed who held the interpreter-ship for the Armenians and for the other ethnic/religious groups in Cyprus. Examination of the documents did not enable us to establish if the interpreters selected from the Cypriot Greeks were also responsible for and held the interpreter-ship for other ethnic/religious groups. This raises the question as to, 'by which organs or officials did the relation between the Armenian population and the state government and court especially in a place like Cyprus where there is a particular number of Armenians,' come to nought?

On the island, there was no official permanently employed making interpreter-ship for the Armenians and this situation shows us that they did not use interpreters, or that they could speak Turkish. The non-usage of court interpreters for the Armenians does not match the manner of Ottoman rule. Even if there was not a permanent Armenian interpreter, and there were a few 
examples, it should be admitted that the proxy which were appointed by the Armenians carried out the role of interpreter-ship on their behalf. For example, Eksabet bint-i Ohan from the Arab Ahmet Paşa quarter appointed Boyacı Haci Ohannes v. Isai from the same quarter as representative in 1872 (Safar, 1289) (KŞS., 51, 54/2). In the same example, it is understood that Boyac1 Ohannes was not only the representative but also the interpreter.

The real reason for there not being a permanent interpreter for the Cypriot Armenians was simply that most of the Cypriot Armenians could speak Turkish. Cypriot Armenians adopted Turkish as their mother tongue. From the examination we made of the documents from the Cyprus Shari'a registers relating to the Armenians, it is evident they gave their testimony themselves and there is no suggestion they used an interpreter. Examples of using proxies do not exceed a few examples. This is very important evidence clearly indicating that the Cypriot Armenians spoke Turkish.

Another source that supports the evidence that the Cyprus Armenians could speak Turkish and even adopted Turkish as their mother tongue is provided from the British period. In the census made in 1891 in Cyprus under British rule, the language status of the people was also recorded. According to the census results, 62 of 280 Armenians showed Turkish as their mother tongue (Çelik, 2012, 254-255). After the occupation of Cyprus by Britain in 1878, the new British goverment needed interpreters in many departments. In order to fill this deficiency, Armenians were mostly appointed as interpreter because they had a command of both Turkish and English (KMA., NE., 174-2, C.2324, 38). This clearly shows why a permanent interpreter was not appointed for the Armenians during the Ottoman period. The Armenians who spoke Turkish had the opportunity to express themselves in court without the help of an interpreter. K. Çiçek has asserted this same opinion (Çiçek, 2002, 8).

Although Cyprus court interpreters were only selected from amongst the Cypriot Greeks, because of the consequences of the Greek revolt in 1821 on Cyprus, (Dinç, 2010, 82-107) after this date, a Turk was appointed to the Nicosia court interpreter-ship for a period. The reason for this was the involvement of court interpreters in 1821 affairs. The old court interpreters Haci Yorgaki (BOA., MAD. d., 9764, 89/5) and the new court interpreters and Hristoğlu s' (BOA., MAD. d., 9764, 378/1) properties were sold off because of their involvement in the events of 1821 and a Turk called Süleyman Nuri was appointed to the court interpreter-ship (KŞS., 30, 3/3).

\section{Last Period of Cyprus Court Interpreters and the Ascendancy of The Court Interpreters}

Haci Yasef v. Şahbaz (Hadji Joseph) was the Nicosia court interpreter in the middle of the $18^{\text {th }}$ century. Haci Yasef is recorded amongst the witnesses in many trial documents (KŞS., 18, 8/1; KȘS., 18, 9/3; KŞS., 18, 13/1; KȘS., 18, 32/1; KȘS., 18, 32/2; KŞS., 18, 35/1; KŞS., 18, 40/1). Although it could not be determined exactly when HaciYasef was appointed to the post and when he left it, after Haci Yasef, Mihail was appointed to the court interpreter-ship in 1761/1762 (1175) (KŞS., 18, 40/1). Haci Yasef is last recorded as court interpreter in 1759/1760 (1173) (KŞS., 18, 35/2), he was promoted to the Cyprus dragomanship (Hill, 1972, 95). So it can be stated that Haci Yasef's court interpreter-ship ended in the year 1761. On the other hand, Haci Yani v. Hristofi is recorded as the court interpreter on documents dating from the year 1763/1764 (1177) (KŞS., 18, 59/1).

A Cypriot Greek called Bollidero v. Luizi was recorded as court interpreter in the year 1790/1791 (1205) (KŞS., 21, 186/2). Bollidero did not last long, he left his office to Nicola (Ali Bey, 1816, 268) in January/February 1792 (Jumada Al-Thani, 1206) (KŞS., 21, 202/1). Nicola, living in the Çatalhurma quarter of Nicosia, was also the city chamberlain at the beginning of the 1800's (KȘS., 29, 9/1) After the Ottoman-French war of 1798-1802, Nicola 
was sent to the Tuzla court with a baliff for the return of real estate that was occupied by the French (BOA., HAT-244/13719). Nicola was good at European languages and this was the main reason for his appointment to this duty. Nicola was the interpreter for the pilgrim Ali Bey on his visit to the island (Ali Bey, 1816, 268).

The relations between the Cyprus rayahs and the Ottoman government were serviced through the bishops, the council interpreter and the court interpreter. The communication between the rayahs and the administration was undertaken by the Bishops on religious subjects and on tax, the council interpreters on tax and administrative subjects and the court interpreters on justice. From this perspective, the court interpreters were amongst the most important representatives of the Cyprus rayahs for the Ottoman administration. This situation enabled the post of court interpreter to gain power and establish great efficacy on the island. Especially in the $18^{\text {th }}$ century, as an indicator of the decentralization seen across Ottoman territory, the bishops, the dragoman on the status of rayah proxy gained great influence, in this respect, the court interpreters became very important (Çevikel, 2000). The office of court interpreter was the first step towards the dragomanship with the status of rayah proxy. Therefore, from time to time the court interpreters played an important role in the politics of the island. Haci Yasef v. Şahbaz and Nicola v. Nicolaki enhanced their influence through holding the office of council interpretership as well.

Haci Yasef v. Sahbaz was the interpreter for the Consulates of Great Britain and Denmark. In this sense Haci Yasef, who was fluent in Western languages, had privileges as the sworn interpreter (KŞS., 20, 83/1; KŞS., 20, 83/2).

Haci Yasef was fluent in Western languages and was made consul interpreter, this shows the effectiveness of Haci Yasef on the island. He was the interpreter for Timothy Turner, proxy for the English and Danish consuls in the years 1763-1768 (KȘS., 20, 83/1; Luke, 1989, 276). Consul interpreters also had privileges written into their berats due to the ahidnames. Haci Yasef as the interpreter for the English and Danish consulates, and his sons and two of his servants were exempt from some taxes and he also had the right to obtain slaves, did not have to pay customs and bazaar taxes, and the lawsuits concerning complaints about him could only be brought to the Divan-1 Hümayun (KȘS., 20, 83/1; KȘS., 20, 83/2). The interpreter Haci Yasef had a wide raft of privileges and this paved the way for his efficiency on the island. Nevertheless, when Haci Yasef became dragoman in 1762, and then consul interpreter in 1763, his efficiency on the island reached its summit (Hill, 1972, 95). When the interpreter Yasef died in 1780, he left his wife Anna and two children behind.

Nicola was appointed to the dragomanship by proxy in 1804, due to the rebellion against the Cyprus Dragoman Yorgaki (Dinç, 2010, 54-73) and his escape to Istanbul and the prohibition of his return to Cyprus (BOA., A. DVN. MHM.d., 221, 296/1, H. Rebi‘ Al-Thani 1219/July 1804). After Nicola was appointed to the dragomanship by proxy, another man Haci Yorgaki $v$. Hristoğlu was appointed to the court interpretership without any delay (KŞS., 24, 2/2). Although Nicola was raised to the dragomanship by proxy, he continued to use the title of "court interpreter" for a while. Thus, in the documents of the end of May 1805 when he became dragoman proxy, his use of this title is witnessed (KȘS., 24, 93/1; KȘS., 24, 93/2).

It was revealed that Nicola made some irregularities after he was appointed to the Cyprus dragomanship by proxy. The weakness of Ottoman government was important for Nicola's misuse of office (Hill, 1972, 116-117). The reason why Nicola misused his office was because of the weakness of the Sublime Porte (Hill, 1972, 116-117). According to news sent to Istanbul, Nicola colluded with the tax collectors and collected more money from the people than was due (BOA., A.DVN. MHM. d., 226, 15/2, H. Rajab 1222/September 1807). 
“... tercümân vekîli nasb olunan Nikola nâm zimmîye havâle olunub mesfûr dahi tama'a teba'iyyet ve muhassillar ile yek-dil ve yek-cihet olarak masârıf-ı belde ez-kadîm ma 'rifet-i şer've cümle ma'rifetleriyle rü'yet olunagelmişken vekîl-i mesfûr hîleye sülûk ve hod be hod külliyetli masârif nâmiyla defterler tertîb ve temhîr ve ber-takrîb temhîd ve fukarâdan cem 've tahsîl eylediğinden başka dâima fukarâyı tecrîm ve tağrîm eylediğinden perâkende ve perîşân olduklarından ...".

It is also possible that this report could be a slander of the Cyprus Greek Orthodox Church in order to cause Yorgaki to be returned to the island. The Cypriot Greek community representatives had determined the name of the Cyprus dragoman up to this time, a man was appointed by proxy, and even he was an old court interpreter, and without their confirmation. The rayahs did not want to lose this power and as a result of their petitions Yorgaki was returned to his work and Nikoki's proxy was ended. As soon as Yorgaki returned to work, he attempted to see the accounts of the old court interpreter, who worked instead of him as proxy (KŞS., 26, 93/3). Thereupon, Nicola who had a good relationship with Muhass1l Hasan Aga complained about Yorgaki to Istanbul, blaming him with misuse of office (Hill, 1972, 116-117). Yorgaki was recalled to Istanbul and later put to death and Nicola regained office (BOA., A.DVN. MHM. d., 227, 112/2). The events at the beginning of the $19^{\text {th }} \mathrm{c}$. were a clear indication of the power and influence of the old court interpreter Nicola on the island.

Court interpreters had considerable power at the end of $18^{\text {th }}$ century and the beginning of the $19^{\text {th }}$ century, but as a consequence of both recent developments on the island and the centralization reforms of the reign of Mahmut II, they lost their old power. While Nicola had great power on island himself, he lost value in the eyes of other representatives of the Cypriot Greek community because of his appointment to the dragomanship by proxy by the Sublime Porte. The bishops who had determined the dragomans amongst themselves, knew they had lost this power and they were against Nicola obtaining this appointment, even though he was the former court interpreter.

Therefore, the old court interpreter Nicola could not be said to have warm relations with Greek society. For this reason, although he had great power on the island, it was not possible for his successors to continue with this same power.

Indeed, Haci Yorgaki v. Hristoğlu, the man appointed to the court interpreter-ship after Nicola, could remain in his position for a few years; Haci Simion was appointed to the interpreter-ship in 1808 (KŞS., 26, 124/2). Haci Simion was sent into exile on the island of Lemnos in 1812, on the grounds of his corruption with Nicosia Kocabaşi Yorgaki. But after two years, upon the assurances their family gave, they were released on the condition they would not commit any further bad behaviour, or they would be put to death (BOA, HAT-299/17754). After Simion, Hristoğlu was appointed to this office (KȘS., 28, 30/3, 1812/H. 1227). The documentary record shows Hristoğlu stayed in office until 1821 (1236).

The period after 1821 was when the court interpreters completely lost their old powers on island. The confusion of affairs in 1821 caused the Cypriot Greek community to lose control on Cyprus and this also affected the court interpreters. Because of the affairs due to the reflection of Greek revolt on Cyprus at this time, a Turk was temporarily appointed to the office of Cyprus court interpreter-ship and this weakened the role of the interpreters.

After the appointment of a Muslim to the court interpreter-ship, the documents do not provide sufficient information concerning court interpreters. The reason for this was the negative attitude of the bishops towards the court interpreters, a consequence of the elimination of the bishops from their role in the appointment of the dragoman in 1804. 
On the other hand, the recalling of Yorgaki to Istanbul when, after a short while, he returned to the island, with a direct appointment from the Sublime Porte instead of him, exaggerated the reactions of the Cypriot Greek rayahs and the bishops to the interpreters. The interpreters who were approved by the Cypriot Greek rayahs and provided communication between them and the administrative and judicial authorities, fell into disfavour as a consequence of these events. Also their involvement in the 1821 affairs weakened their prestige in the eyes of the state management. This resulted in less space being given in the documents to court interpreters.

A Cypriot Greek holding the post of court interpreter could only be found on the $1^{\text {st }}$ of April 1841 (8 Safar 1257) after the 1821 events. On this date, the court interpreter was a Cypriot Greek named Haci Yorgi (KŞS., 38, 180/1). A short while later, Haralambo Plavaki, a Cypriot Greek from the Aya Andoni quarter of Nicosia (KŞS., 39, 32/2), became the court interpreter in July 1841 (Humada Al-Awwal 1257) (KŞS., 38, 208/1).

Another Cypriot Greek Hristofaci v. Gavrili was court interpreter at the beginning of 1856 (Jumada Al-Thani 1272) (KȘS.,44, 70/1). It is seen that this person was also court interpreter in 1866 (1283) (KŞS., 47, 151/1). Evidence that the court interpreter-ship of Hristofaci v. Gavrili lasted until 1872-1873 (1289) can be obtained from the documents. Hristofaci was recorded among the witnesses until this date (KŞS. 51, 37/2; KȘS., 51, 42/1; KȘS., 51, 54/1) and continued as proxy for the parties (KŞS., 51, 40/1).

A debt lawsuit was filed by Haris bint-i Lefteri from Vadili village against the court interpreter Hristofaci in 1863-1864 (1280). In the related lawsuit Haris bint-i Lefteri claimed Hristofaci owed 50 piasters to him from the legacy of his father, although Hristofaci denied this debt, but Haris bint-i Lefteri proved his claim through witnesses (KMA., Zabit Defteri, 10, 5/1).

An interpreter named Rafael Delyando was employed with 600 piasters of salary when a trade lawsuit began on Cyprus in 1865 (Samani, 2006, 213). But this interpreter in the trade court did the interpreter-ship for European merchants not for the rayahs, unlike his colleagues in the Shari'a courts.

\section{The Economic Conditions of Court Interpreters}

The economic power of the court interpreters was also quite significant as they were considered the representatives of the Cypriot Greek subjects. Their property income is unclear, but a certain amount of monthly salary was being allocated to the interpreters. Besides the salary, court interpreters received a significant sum from litigants for their service in the court (Çiçek, 2002, 12). For example, when Nicola became a court interpreter, he was awarded a monthly salary of 150 piasters which was met by the rayahs (KŞS., 28 (Ek), 7/9). Another court interpreter whose salary can be determined from the documents was Hristofaci v. Gavrili. The salary of Hristofaci in 1862 was 1.500 piasters which was met through taxes raised from the Cypriot Greek rayahs. However this salary was very low when compared the provisions of the period, permission for fiscal custody was requested in order to increase the salary from an increase in rayah taxes (BOA., MVL., 788/41).

It should be understood that the salary given to the court interpreters was not their only source of income. Interpreters made large gains in commercial and real estate transactions, especially during their term in office they gained great power and domination. So, for example, the court interpreter Haci Yani v. Hristofi bought two properties in the Aya Sava quarter costing fifty seven piasters (KŞS., 19, 79/2) and sixty one piasters (KŞS., 19, 79/3) respectively; olive trees and other fruit trees with a reed bed and also a seven acre field in the village of Pano Deftera with water rights for two hundred and seventy piasters (KŞS., 19, 81/1) from Dizdar Mustafa Ağa b. Hasan. Muhzırbaşı Molla Ali b. Süleyman from the Mahmut Paşa quarter died owing a 520 money debt to the court interpreter Haci Yani v. Hristofi. 
The court interpreter Nicola was involved in several commercial activities, he was from the Big and Small Hagia Sophia and he rented two mills in exchange for a total of 6.500 $(4.500+2.000)$ piasters cash, a monthly total of $115(75+40)$ money for 99 years on the $15^{\text {th }}$ of April, 1805 (KŞS., 24, 93/1; KŞS., 24, 93/2; KŞS., 24, 93/3). But his commercial activities did not prosper and when he died at the beginning of 1815 (1230) he left debts of 19.760 piasters, more than his inheritance of 9.576 piasters, 30 money (KŞS., 29, 9/1).

\section{Conclusion}

The court interpreters, who formed an important aspect of the organization of the Ottoman judiciary, had been employed from after the conquest on Cyprus due to its significant population of rayahs. The first identified interpreter was in the year 1610, named Toma.

The result of the examination of the Nicosia Shari'a Registers showed that the majority of the court cases of Non-Muslims took place amongst themselves. This situation reveals the rationale for the employment of Cypriot Greek interpreters in Nicosia. With the weakening of the central authority of the Ottoman state, the Cyprus court interpreters who gained political and economic power established efficiency in the island. It was not necessary to employ interpreters who spoke Armenian as a significant number of the Cyprus Armenians spoke Turkish.

The duty of the court interpreters, who were selected from the Cypriot Greek community, was to interpret to enable the rayahs to advocate their rights in courts, translating the papers that were given from the courts and which were given to the courts and agency tasks, serving as reliable people when needed. Thus, they had an important role in the manifestation of justice, the primary reason for the employment of court interpreters.

\section{REFERENCES}

Atar, F. (1979). İslam Adliye Teşkilatt. Ankara: Diyanet İşleri Başkanlığı Yayını.

Çelik, C. (2012). Ingiliz Yönetiminde Kıbrıs’n İdari ve Sosyal Durumu (1878-1914). Yayımlanmamış Doktora Tezi. Akdeniz Üniversitesi, Antalya.

Çevikel, N. (2000). Kıbrıs Eyaleti: Yönetim, Kilise, Ayan ve Halk (1750-1800). Gazimağusa: Doğu Akdeniz Üniversitesi Yayını.

Çiçek, K. (1996). "Osmanlı Adliye Teşkilâtında Mahkeme Tercümanları". Toplumsal Tarih, 30, 47-52, Tarih Vakfi Yurt Yayını.

Çiçek, K. (2002). "Interpreters of the Court in the Ottoman Empire as Seen from the Sharia Court Records of Cyprus". Islamic Law and Society, 9/1, 1-15.

Çiçek, K. (1992). Zimmis (Non Muslims) of Cyprus in the Sharia. Court: 1110/39 A.H. / 1698-1726 A.D. Yayınlanmamıs Doktora Tezi. University of Birmingham, Birmingham.

Dinç, G. (2010). Osmanlı Yönetiminde Kıbrıs (1800-1839). Yayımlanmamış Doktora Tezi. Akdeniz Üniversitesi, Antalya.

Domingo, B. L. (1816). Travels of Ali Bey. I, London: Longman.

Ekinci, T.B. (2004). Tanzimat ve Sonrası Osmanlı Mahkemeleri. İstanbul: Arı Sanat Yayınları.

Erdoğru, M. A. (2001). "The Judicial Court in Ottoman Cyprus (1580-1630)". Tarih Incelemeleri Dergisi, 16, 9-19. Ege Üniversitesi.

Gerber, H. (1994). State, Society, and Law in Islam: Ottoman Law in Comparative Perspective. Albany, New York: State University of New York Press.

Hallaq, W. B. (2009), Sharī'a. Theory, Practice, Transformation. Cambridge: Cambridge University Press.

Hill, G. F. (1972). A History of Cyprus. IV, Cambridge.

Jennings, R.C. (1978a). "Kadi, Court and Legal Procedure in $17^{\text {th }}$ Century Ottoman Kayseri". Studia Islamica, XLVIII, 133-72.

Jennings, R. C. (1978b). "Zimmis (non-Muslims) in the Seventeenth Century Ottoman Records: the 
Sharia court of Ottoman Kayseri”. Journal of the Economic and Social History of the Orient, XXI/3, 225-93.

Jennings, R. C. (1993). Christians and Muslims in Ottoman Cyprus and the Mediterranean World (15711640). New York: New York University.

İnalcık, H. (1957). "Mahkeme". İslam Ansiklopedisi. VII, 149-151. İstanbul: Milli Eğitim Basımevi.

Lambton, A. K. S (1994). "Pishkash: Present or Tribute". Bulletin of the School of Oriental and African Studies, 57, 145-58.

Luke, H. (1989). Cyprus: Under the Turks (1570-1878). London: C. Hurst \& Company.

Orhonlu, C. (1975). "Osmanlı Devleti’nde Tercümanlık”. Atatürk Konferansları V. Ankara: Türk Tarih Kurumu Yayını.

Orhonlu, C. (1979). “Tercüman”. İslam Ansiklopedisi, XII. İstanbul: Milli Eğitim Basımevi.

Ortaylı, İ. (1994). Hukuk ve İdare Adamı Olarak Osmanlı'da Kadı. Ankara: Turhan Kitabevi.

Peirce, L. (2003). Morality Tales: Law and Gender in the Ottoman Court of Aintab. Berkeley and Los Angeles: University of California Press.

Samani, H. (2006). Tanzimat Devrinde Klbrıs (1839-1876). Yayımlanmamış Doktora Tezi. Hacettepe Üniversitesi, Ankara.

Veinstein, G. (2000). "The Ottoman Administration and the Problem of Interpreters". The Great Ottoman Turkish Civilization, 3. 607-615. Ankara: Yeni Turkiye Yayını.

\section{Archive Documents}

Cyprus Shari'a Registers (KŞS).

No: 3-6; 24; 18-21; 25-26; 28-30; 38-39; 44; 47; 51.

Turkish Republic of Northern Cyprus National Archives and Research Department (Kuzey Kıbrıs Türk Cumhuriyeti Milli Arşiv ve Araştırma Dairesi, KMA).

NE., Rare Collections (Nadir Eserler Koleksiyonu), 174-2, Cyprus. No. 2 (1879). (C.2324) Corrospondence Respecting Complaints Made Against the Goverment of Cyprus, Printed by Harrison \& Sons, London).

Minute Book (Zabit Defteri), No: 10 (H. 1282-1283/A.D. 1864-1866).

Prime Ministry Ottoman Archives Documents (Başbakanlık Osmanlı Arşivi Belgeleri (BOA).

BOA., HAT-244/13719.

BOA., HAT-299/17754.

BOA., MVL-788/41.

BOA., MAD.d., 9764.

BOA., AE.SMST.II.-37/3634.

BOA., A.DVN.MHM.d., 221.

BOA., A.DVN.MHM.d., 226.

BOA., A.DVN.MHM.d., 227. 
